\title{
Conferences of Arica and American diplomacy during the nitrate war 1879-1883
}

\begin{abstract}
This study rebuilds the lesser known attempts and diplomatic efforts carried out by the world powers during the development of the so-called War of the Pacific. The study focuses on analyzing international controversies emerging from international interests over wealth and territories of the belligerent states, as well as analyzing diplomatic efforts and good offices in Arica's Conferences. Furthermore, the role of the press during the monitoring and evaluation of events is analyzed, considering factors which prevented Chile, Perú and Bolivia to sign a peace treaty with United States' mediation. The purpose of this article is to unveil the potential peace scenarios, derived from diplomatic efforts promoted by representatives of world powers, who had commercial interests engaged during the development of the Nitrate War (1879-1883).
\end{abstract}

Volume 3 Issue I - 2018

Hugo Castro Valdebenito, Alessandro
Monteverde Sánchez
Department of History, University of Playa Ancha, Chile

Correspondence: Hugo Castro Valdebenito, Department of History, Faculty of Humanities, University of Playa Ancha, Chile, Email hugo.castro@upla.cl

Received: July 29, 2017 | Published: January II, 2018

Keywords: lackawanna, arica's conferences, diplomacy, nitrate war, saltpeter war

Abbreviations: NAUSA, national archives of the united states; MINREL, ministry of foreign affairs of chile

\section{Introduction}

\section{Historical background on the war of saltpeter}

The first political constitutions of Chile indicated that the national territory stretched from the Atacama Desert to Cape Horn. Different scholars have argued that it would include the despoblado of Atacama. ${ }^{1}$ For his part, the internationalist and Peruvian diplomat Víctor Maúrtua, in his plea for bordering issues regarding Bolivia, expresses that the Audience of Lima bordered with the Kingdom of Chile, in the boundary that was in the parallel 21, at the mouth of the Loa River. ${ }^{2}$ However, Bolivian historians claim that the Audience of Charcas, predecessor name of their country, had coastline in the Pacific Ocean, extending from the previously mentioned river and up to the border with Chile, in the parallel $26 .{ }^{3}$ Among other background, they rely on a map of the province of Potosi, drawn by Hilarion Malaver in 1787, which showed that the General captaincy of Chile limited with the Audience of Charcas in the Salado River, near the parallel 26a'15' close to Copiapó. Current Bolivia's Charcas, would effectively have, by colonial inheritance, a way to the Pacific Ocean. ${ }^{4}$

In the Chilean-Argentinean boundary dispute which was submitted to the arbitration of the British Government in 1896, the diplomatic team of Chile stated that the Republic of Bolivia, reached to the Pacific sea in the territory of Atacama, in the Northern Chilean limits. ${ }^{1}$ A demarcation established in reputable Cano and Olmedilla mapping of 1775. As it is, Charcas, in the current Bolivia, had sea since colonial times. $^{2}$

As a consequence of the war against Spain in which Chile and Bolivia were allies, along with Peru and Ecuador, controversial findings were finally settled by the Pact of 1866 , which established

${ }^{1}$ Exhibition that on the part of Chile and in response of the Argentine Exposition is submitted to the Court that constituted the Government of S.M. British in its character of Arbitrator appointed by the Agreement of April 17, 1896 Paris, France. 1902.

${ }^{2}$ El Mercurio, Santiago, January 19, 2014. Letter from the academic José Miguel Barros to this newspaper the border in the 24th parallel, then the 1874 pact can confirm the agreement that put an end to economic condominium that was established in 1866. In exchange for this, for a period of twenty-five years, Bolivia pledged that the Chilean people, capital and industries located in the area, where Chile renounced its territory North of the parallel $24^{\circ}$ would not be "subject to more contributions of any kind, that which at present exist". He agreed mediation cases that may arise from intelligence issues and enforcement of the previously mentioned bilateral instrument. The Peruvian-Bolivian historiographer had tried to show that Chile was a nation without an economic destiny. And because of that, it would have sought to expand into Bolivia and Peru ${ }^{5,3}$ forcibly occupying lands that never belongs to it. But it is important to indicate that this was not a State policy, but rather a course of actions led by the private sector and its men.

The facts do not correspond with the allegation of Chile being a poor country. In fact, in 1832 the rich mineral of silver was discovered at Chañarcillo mine, near Copiapo. Soon after, Jose Tomas Urmeneta mined a valuable vein of copper in Tamaya, which made him the first worldwide producer of that mineral. Furthermore, down South, Matías Cousiño developed the coal industry, mutatis mutandis which can be compared to the current oil industry in the modern world. And we cannot forget the agricultural central zone of Chile, with the fertile valleys, of Aconcagua and Casablanca. But, more important, it was the constitutional stability that reigned for several decades, in conjunction with political elite that, in spite of the conflicts and power struggles, knew how to uphold its power.

In view of these facts, Chilean and British employers established themselves in the Despoblado of Atacama from 1830. The territory was practically uninhabited and it was thought to be of no commercial value. These entrepreneurs discovered great wealth which soon became a source of considerable resources for their own benefit. Together with the Chilean workers, they went to constitute here, the most important human presence. On the other hand, the Bolivian population was nothing but a few government officials. Lured by silver, guano and saltpeter, considerable fortunes in Chile were created, as well as better

${ }^{3} \mathrm{He}$ contradicts the Bolivian historian, Valentin Abecia, who in "History of the diplomatic relations of Bolivia", maintains that Chile expanded towards the north because of the paralysis of its economic development. 
paid working wages, generally very underpaid in the haciendas of the central zone. The situation of the Peruvian province of Tarapacá was somewhat different. Recent studies indicate that previously to the War of Saltpeter, Peruvians owned a little more than half of the saltpeter companies (50\%) and Chileans about one-fifth (20\%). The British have nearly a $13.5 \%$ and Germans $8 \%{ }^{6}$

In 1876 the President of Bolivia Tomas Frias, was deposed by a military coup, led by his Minister of War, General Hilarion Daza. His countryman, the historian Alcides Arguedas has described the latter as a man "of burning temper, greedy, sensual and free of any moral scruple". ' Daza arbitrarily established a tax of ten cents per quintal of nitrate exported to the company of saltpeter and railroads of Antofagasta, which violated provisions of the Treaty of 1874 . The company was formed by Agustín Edwards and Francisco Puelma, with 848 shares each and the British Guillermo Gibbs, with 804 . Company associates were affected by this provision and feared that the Government of Chile would inhibit to take action. "As Chile has or intends to have, saltpeter lands of their own-wrote Hicks, General Manager of the Gibbs House, to his parent in Valparaiso - your opposition, I fear, will be weak. ${ }^{8}$

What attitude would Chile take? Of course, Chile crossed by a difficult economic situation, while on the external front, was facing important problems bordering Argentina. It is true that it had approved in Buenos Aires the Fierro-Sarratea Pact, but its ratification by the Argentine Congress was still pending. If the rulers of the Palace of Toesca had reminded the secret associated Treaty of 1873, they would have understood that they would have two opponents instead of one and then have, perhaps a third, if Argentina had signed in. That was the situation that we care about addressing, so from a historical background, introducing the role of diplomacy in the preview of the conflict. We will not attend war facts, as they are already, pretty known, for participants in the conflict.

\section{Methodology}

For the development of this research, a bibliographic review was carried out in order to determine the various diplomatic occasions that under the aegis of US interests sought to end the international conflict. According to the results of the bibliographical research, the authors who scarcely address these diplomatic experiences were identified. This bibliographical review was complemented with a hermeneutic strategy of work in documentary archives. To this end, the historical documentation of the Ministry of Foreign Affairs of Chile, the notebooks of letters and diplomatic communications and a record of the communications between the United States and Chile were investigated and analyzed.

\section{First reactions of the neutral parties}

Not yet declared the war, in February 1879 the Chilean army occupied the Bolivian port of Antofagasta without resistance and advanced the next month towards the interior of the province, where the first armed battle of Topater occurred and which led to the capture of Calama, a provisioning point for the Bolivian troops. The question is: how do some foreigners appreciated these facts? The New York newspaper Nation believed that the origin of the war "should be traced in envy and dismay that poorly governed Nations were experiencing when contemplating the success of Chile, that develops resources, that them having the same access were Unable to use on their own".? For the New York Herald, the cartography certainly allocated the disputed territory to Bolivia. However, entrepreneurship and the maritime feasibilities were what gave Chile the possibility of settling in territories traditionally belonging to the high plateau country. The mentioned media added, that Peru wanted to hold a monopoly of nitrate and that the true Chilean fight was against Peru, not Bolivia. ${ }^{9}$ On the other hand, the Baron Guilich, German representative in Santiago, expressed his opinion in an official communication to Berlin

"The nitrate issue certainly gave the last external impulse the Chilean/Bolivian war, but the true cause of the current war, however, is much more profound; it is the bitter envy, vivid hatred that has prevailed years in Peru and Bolivia against Chile for many years. These unfortunate countries, continually torn apart by revolutions and mismanagement, envy the material prosperity that Chile reached so far, its ranked political life, not disturbed by revolutions and not interrupting growth. The fact that Chile, earlier this year, was completely dismantled on land and at sea, the standing army was limited to the minimum, its National Guard licensed and its warships without enlisting and even offered for sale, show, in my opinion, that Chile didn't even remotely thought in a war with Peru and Bolivia; the war was made necessary by the proceeding of the Bolivian Government with the Chilean nitrate owners. On the other hand, the secret Treaty of 1873 between Peru and Bolivia, which only became known, to declare war, shows that there were hostile intentions against Chile. Chileans who lived in Peru and Bolivia were harassed by the authorities and by the nationals, while the Peruvians and Bolivians living in Chile continued their lives without anybody being bothered about it.". ${ }^{10}$

The Emperor of Brazil Dom Pedro II, judged that Bolivia acted poorly by imposing a tax on Chilean companies that were protected by a treaty, on the contrary Chile reacted well and proceeded to terminate it and to occupy the disputed territory. Given that it had a secret pact involving Bolivia, Peru been signed, in his opinion should strive so that Bolivia could avoid a war. ${ }^{11}$ European countries, especially Great Britain, France and Italy, had a marked concern about the financial situation in the old Spanish Viceroyalty. Peruvian debt contracted almost entirely, with them and amounted according to US sources, to 281.340 .000 dollars. Bondholders were subjects or citizens of the old continental Nations. They went to their foreign offices, their parliaments and the press, in demand of protection. Peru, on the edge of the bankruptcy, in 1876 suspended payment of the interest and the principal debt in $1878 .{ }^{4}$

This was the cause that began to shuffle the possibility to carry out interventions, some friendly and other less, in order to put an end to the war. When the conflict started formally, the United States Secretary of State, FW Seward, declared that the US would be neutral. ${ }^{12} \mathrm{He}$ offered his services, only when they were requested. Indeed, he showed no concern when Chile occupied Antofagasta. Apparently, there is no committed US economic interest. However, soon would start their fears led by possible European interference in the Western hemisphere. According to the declarations of US President Monroe in 1823, this in time would be known as the Monroe doctrine ${ }^{13}$ only allows action in continental conflicts, to the Americans, not the Europeans. Washington spoke against any extra-continental armed intervention. ${ }^{5}$

${ }^{4}$ "Statesman's tear Book "of the same year, the Chilean debt amounted to $63,000,000$ dollars.

${ }^{5}$ NAUSA/52-32, Oficio $n^{\circ}$ 53, Lima, 10 de septiembre de 1879, de Isaac P. Christiancy, Ministro de E.E.U.U en Perú, a William M. Evarts, Secretario de Estado 
The United Kingdom offered its good offices in Lima Representatives from England and Italy invited their French peer to cooperate in this regard. These attempts, however, did not succeed as they were refused by Peru, ${ }^{6}$ while Chile accepted them, in accordance with the message that President Aníbal Pinto gave to the National Congress. ${ }^{14}$ Britain reinforced their naval presence and received German support. Bismarck talked with the Berlin stationed American Minister, to offer the parties a joint mediation, in order to protect neutral trade, in other words, their commercial interests. The Secretary of State of the United States William M Evarts immediately spoke out against the German intention. He gave as an explanation that United States would not adopt measures that seem to be coercive and in detriment to the rights of the warring States. ${ }^{15}$ Obviously underlying the mentioned Monroe doctrine "On April 17, the American Plenipotentiary Minister in Lima, Isaac P Christiancy, together with their colleagues from Britain, France, Italy and the German Chargé affairs, sent a memorandum to the Chilean Admiral Juan Williams Rebolledo which requested" respect for life and neutral properties". Evarts supports it and rejected the use of non-humanitarian methods in the war. ${ }^{16}$

The first weeks of the conflict showed that Chile had no preparation to undertake an operation of such magnitude. The performance of the Almirante Williams Rebolledo, was not comparable with the Peruvian Miguel Grau. The fearsome Peruvian armored monitor, The Huáscar, that according to British sources could count among the best and most useful of the world, "he toured the Chilean coasts without opposition" public opinion was disoriented and vexed and the press, were set themselves to their favorite sport: criticism of the authorities, in this case, otherwise deserved. On May 21, 1879, a captain on board of the Emerald ignited a patriotic fiber in Chile that slept at the bottom of national sentiment. In that episode, Peru lost the Huáscar, one of the two most powerful vessels of its fleet and Chile an old boat. However, he earned worldwide recognition and admiration. The Times of London qualified it with these words: this is one of the most glorious battles that never took place. An old wooden vessel almost falling apart held action for three and a half hours against a battery of land and a powerful battleship and concluded with their flag on top. ${ }^{17}$

Since then, the slogan was to fight to the death without taking into account the power of the adversary. ${ }^{18}$ Subsequent to these events, the Peruvian Government ordered the purchase of Lay torpedoes, in order to sink the armored enemies and achieve the surrender of Antofagasta. This operation was commissioned to Commander Grau, who set sail from Arica on August 22, 1879. However, while the Huáscar glided around the Bay, it was discovered by a Chilean surveillance boat. The operation failed and one of the armored vessels managed to escape the attack, its collapse would have had dire consequences for Chile.

\section{United States diplomatic management in La Paz, Bolivia}

Judge Newton Pettis, before assuming his functions as resident minister resident in Bolivia, had an informal meeting with the President of the United States in the first days of April of 1879, in

${ }^{6}$ Pascual Ahumada (1982) Guerra del Pacifico. Editorial Andrés Bello, Santiago, Tomo I. Transcribed notes from Spencer St. John, British Minister in Peru, April 24, 1879, and the reply of Manuel Irigoyen, Minister of Foreign Affairs of Peru, April 28, 1879.

"Informes inéditos de diplomáticos extranjeros durante la Guerra del Pacifico" Editorial Andrés Bello. Santiago 1980. Office 53, Santiago, July 12, 1879, by Baron Gulich, Minister of the German Empire in Chile to Minister of State Von Bulow. p. 19 which the ruler, without further details, expressed his desire to end the conflict. Pettis gave health reasons as a pretext and moved to the coast of the Pacific, from Bolivia, in order to carry out a mission without authorization of the US State Department. He was not prepared to dictate peace or to intervene, even thought if the Parties requested his good offices on the basis of arbitration, he, the President of the Union ${ }^{19}$ would have to employ them. Pettis, lacking instructions, intended that American Arbitration would put end to the war. The arbiters could be the President of the American Union or the Supreme Court, or an ad hoc tribunal consisting of Ministers in La Paz, Santiago and Lima. Osborn worked in Chile as Plenipotentiary and had greater rank than Pettis. He did not share his course of action. There were certainly no instructions. In addition, he considered that the allies intended a status quo before bellum prior to start negotiations and Chile simply a status quo that is, keeping the occupied Bolivian territory while the arbitration took place. ${ }^{8}$

In contrast, the candorous and spontaneous judge believed that it was enough to negotiate in order to find conciliation formulas. A wellintentioned man, not having the foresight to anticipate the hurdles that would make him stumble later. He got exited with the declarations made by finance minister, Eulogio Doria Medina, one of the instigators of war. ${ }^{20}$ In view of this, Pettis moved to Lima, where he believed to find a good reception from Chancellor Irigoyen. In Arica, he then, met with Presidents Prado and Daza.

Jorge Huneeus, Deputy Minister for Foreign Affairs, urged on by the anti-war mood of the President of the Republic and with a good dose of candor was also interested because Pettis would travel to Santiago. Thinking that diplomat would be backed by United States. Chile would retain the position of the territory between the 23 and 24 South latitude parallel, given that the population was almost exclusively Chilean. In return, would grant Bolivia monetary compensation, in exchange for its questionable rights. ${ }^{9}$ With respect to Peru, it would appeal to the 1873 Treaty and would give assurances that it would not sign another similar. Also, it would pay a compensation for costs and damage to Chile, by its deceitful and insidious conduct offering itself as a mediator, in circumstances in which it was secretly allied with Bolivia. For additional security, Huneeus request a memorandum to Pettis. The judge stipulated that, at a default date, hostilities would cease; Chile would vacate all the territory north of the parallel 23, withdraw its forces and let a free access to the coastal shores ten minutes south of that parallel to Bolivia, regarding everything else status quo would be ensued.

Huneeus expressed that the Government should submit the existing issues with Bolivia to US Arbitration, according to the proposed bases. Even more, when Peru recalled the Treaty of 1873 and the mediation this offered. Before accepting, The President would consult the National Congress and would heed the feel of public opinion. On August 14 El Mercurio, vehemently attacked the claim to American arbitration and summoned President Pinto to be firm. Osborn noted with skepticism the involvement of its colleague, as well as the naivety of Pinto and Huneeus. He estimated that between Chile and Peru, there was a deep-rooted feeling of enmity and antagonism, to achieve supremacy on the Pacific. ${ }^{10}$ Callao was the main port until independence and Peruvians looked resentfully to Valparaiso for

${ }^{8}$ NAUSA Vol. 10-30. Office No. 110, Santiago, August 9, 1878, by Thomas A. Osborn, US Minister in Chile, to William M. Evarts, Secretary of State.

${ }^{9}$ Minrel Reserved documents of the minutes of the council of ministers referring to the war with Peru and Bolivia. Session of the 9 of August of 1879. ${ }^{10}$ Diario El Mercurio, de 14 de agosto de 1879 P. 2. 
disputing it’s crown. From Lima, the American Plenipotentiary, Christiancy reported that diplomatic intervention would only succeed when Chile or the allies had suffered a major setback. ${ }^{11}$

As we can observe, US diplomacy was characterized initially by an apparent Washington disinterest, as well as the contradictory positions of their representatives in the three capitals. There was a tendency to sympathize with the Government to which they were accredited. Anosther factor that locked US action was its geopolitical remoteness with events.

\section{Action european diplomacy, the conferences of Africa}

On October 8, 1979, near the shores of Angamos the Chilean battleships Cochrane white and the Peruvian monitor Huáscar clashed. The Union Corvette, slipped. However, Peruvian sources indicate that it was not to take part in the battle. ${ }^{12}$ After all the arduous fighting, Admiral Miguel Grau died, beaten by the Chileans Latorre and Riveros. The captured Huáscar, was incorporated into the Chile Navy. Chilean triumph is just a matter of time, said the French publication L' Année Militaire. ${ }^{21}$ The French Minister in Lima deemed that the maritime war had been finished and that it was time to sign peace. A similar judgment issued the Baron of Gülich. From Lima, on the other hand, Christiancy, had transmitted to Washington that the capture of the Huascar, destroyed at that time, all possibilities for peace negotiations. In his opinion, this "would be achieved by means of pecuniary compensation, disturbing the borders as little as possible". ${ }^{22}$ The conflict on the Pacific began to worry the banks of the Potomac, from the moment that it seemed the old-world powers may try to put a direct end to the conflict, in order to defend their economic and commercial interest. For this reason, the President of the United States, Rutherford B. Hayes, December 1st 1879 in his third annual message to Congress, decided to offer his good offices to the warring parties, with a peace seeking intent, "according to honorable bases and to avoid exta-continental interventions". ${ }^{13}$

In this picture, other foreign interpositions are conceived. Gladstone, the English Prime Minister, on January 1880, requested European Governments and the US to intervene. Bismarck refused to participate. The Secretary of State Evarts uneasy informed his agents in the south that Europe pretended to put pressure on the allies. If these intentions would have taken a coercive character, the United States should achieve, without any loss of time to have the belligerents accept his good offices before all else. It was essential to act according to the Monroe doctrine.

A week later, José Carlos Tracy, Peruvian Minister in Washington, convened with the Secretary of State, so he could ensure the neutrality of the Empire of Brazil. Meanwhile, the allies invited the Argentina Confederation to unite against Chile. Evarts immediately disqualified this reckless proposal and pointed out the danger of a European intervention, later he recommended working to prevent such a scenario. ${ }^{23}$ Agents from Italy, France and Britain spoke with Nicolás Piérola, the Chief de-facto in Peru. The latter had taken power over and replacement General Prado. European diplomats found a reluctant attitude in Pierola, who clearly expressed, it inappropriate

${ }^{11}$ NAUSA Vol. 10-30. Office No. 110, Santiago, August 9, 1878, by Thomas A. Osborn, US Minister in Chile, to William M. Evarts, Secretary of State.

${ }^{12}$ NAUSA Vol.52-32 Office No. 47, Lima, August 26, 1878, by Isaac Christiancy, US Minister in Peru, to William M. Evarts, Secretary of State

${ }^{13}$ NAUSA T.52-32 Office No. 64, Lima, October 14, 1878, by Isaac Christiancy, US Minister in Peru, to William M. Evarts, Secretary of State. to make peace and that he preferred the diplomatic corps to refrain from intervening. They reported the meeting back to his colleagues in Chile. They interviewed themselves with President Pinto. Ultimately, Chile would have kept its conditions consecion of Tarapacá River till the Camarones River and respect for the rights of individuals under international law.

President Piérola knowing that his Chilean counterpart would send an agent to Lima to negotiate peace, now responded to the diplomats who would appoint a Plenipotentiary Minister to the cause; but with the condition that there were no territorial encroachments, especially if it was of a definitive nature. The European representatives handed him a document with the Chilean position. He received it in silence, allowing them to anticipate the failure of mediation. ${ }^{24}$ United States began new efforts, in view of the European diplomatic failure. On August 6 Evarts instructed Osborn, in order to put pressure on Chile to achieve peace. The agent spoke with president Pinto and Chancellor Valderrama. Despite the evident public hostile opinion, they thanked him for the mediation, but they pointed out that they understood it in the form of good offices. ${ }^{25}$ This mediation, would take place on an American warship, somewhere off the coast of the Pacific and Evarts would appoint several ambassadors representing him. President Pinto, who did not want to displease the United States, agreed, but added, "the Government will not renounce Tarapacá"14, the most coveted trophy of the conflict. The US State Department approved Osborn's performance and via mail transmitted to Lima and La Paz the result of its management, although it failed to tell them that the land transfer was a prerequisite. This inadvertence, represent a tremendous mistake, since Chistiancy and Pettis knew that Peru and Bolivia would opposed to Chile withholding Tarapaca and Atacama. ${ }^{26}$

Peru and Bolivia made present that they preferred arbitration along with an armistice, during the conferences. And after some other disputes, also giving thought to the place of the meeting as well since Peru opposed to it being held in Arica On October 22, 1880, on the Bay of Arica, it was conducted, aboard the Corvette Lackawanna, of property of the United States Navy. The Ministers Osborn, Christiancy and Adams representing United States, the first higher-ranking minister, Chile was represented by Eulogio Altamirano, Eusebio Lillo and José Francisco Vergara, meanwhile Peru by Antonio Arenas, Aurelio García, Bolivia by Juan Crisóstomo Carrillo and Mariano Baptista.

What was the personality of these negotiators? That was an interesting question, because of them the so awaited peace could come or the indefinitely continuity of war. Altamirano, who presided the Chilean delegation, had been Interior Minister during the Government of Federico Errázuriz Zañartu. Attended Arica without any enthusiasm; however President Pinto sought peace and did not want to refuse Evarts offer. Eusebio Lillo, famous for having composed the lyrics of the national anthem of Chile, during the war was Secretary General of the national squad. In May 1880, he served as Plenipotentiary and agreed on the basis of a separate peace with Bolivia. Their presence intended to them sway away from their Bolivian allies. José Francisco Vergara, very close to President Pinto, acted in the campaign of Tarapacá. After Rafael Sotomayor death, he was appointed war in campaign Minister. Their intervention in Arica was emphatic, a resounding no to the arbitration and a yes to the territorial transfer.

${ }^{14}$ Memorandum of the conferences in Santiago, August 10, 1880, Transcribed note of Melquiades Valderrama to Thomas Osborn, of October 7, 1880 
Arenas acted as President of the Peruvian delegation. He had occupied the Dean's office at the College of lawyers of Peru. At the second term of General Castilla, he was Foreign Minister for a brief time. He directed the American Congress of Jurists which functioned in Lima since 1877. The Navy officer Aurelio Garcia conducted a diplomatic mission in Japan and latter was appointed Interior Minister. Carrillo was a Bolivian Foreign Affairs minister and friends with Eusebio Lillo, Baptista had signed the Pact limits in 1874. The Bolivian Foreign Minister apologized not attending this meeting, alleging a serious indisposition caused by the sea (sea sickness). ${ }^{27}$ Osborn announced that his colleagues and he would not be part of the negotiations, since his role ended when the Plenipotentiaries met. ${ }^{28}$

Altamirano, through a Bill, pointed out the essential conditions demanded by Chile to reach peace, respectively:

A. Perpetual and unconditional concession of the Territories South of the river Camarones, , South of Arica;

B. A solidarity payment of 20 million, a fifth in cash

C. The return of properties that were stripped to Chilean citizens in Peru and Bolivia

D. Reinstatement of the Rimac transport

E. The repeal of the associated secret Treaty of 1873

F. Chile would retain the territories of Moquegua, Tacna and Arica until the fulfillment of the previous commitments.

G. The port of Arica would remain stripped of any military presence forever, if it were to be returned to Peru. ${ }^{29}$

At the same time Pierola in accordance with Bolivian wishes, transmitted the delegates the following conditions:

a. Immediate vacancy of the Bolivian and Peruvian territory and return the situation prior to the occupation of Antofagasta

b. Return the Huascar and the Pilcomayo to Peru

c. And, Chile would pay compensation for the war costs incurred by the allies. ${ }^{30}$

In the event that Chile would not accept to leave the territories or make any other demands, Peru and Bolivia will find the following declarations unacceptable and request further arbitration. ${ }^{15}$ Peru would take the initiative. If Chile refuses, it would only fortify our respective position in the war effort and added naively, "with real damage to them". So, with no further analysis, for it is clear how the first conference went, it concluded at first attempt to agree on points of convergence that would otherwise bring peace, a diplomatic peace.

On 25 October, the second meeting took place. Altamirano announced the Chilean position. The allies objected to it. Arenas with greater emphasis: arguing that Tarapacá, Arica, Tacna and Moquegua have always been Peruvian. He linked the Chilean demands, with the right of conquest, oblivious to the Spanish-American traditions and request mediation by the United States. Altamirano expressed that "in America rectification frontier cases were numerous and that in the supposed Chilean conquest, there is only one new point and it is that of territories are what they are due to the effort and the work of the Chilean people". ${ }^{31}$

${ }^{15}$ Pascual Ahumada, óp. cit. tomo VI. Pág. 349. Transcribed circular of Jose Manuel Balmaceda, Minister of RR.EE of Chile, to the diplomatic agents of the Republic, Santiago, 24 of December of 1881.
Osborn was surprised to the refusal by Arenas. Indeed, when Christiancy meet in Santiago with Valderrama, he stated that Peru would give the Tarapacá. ${ }^{32}$ Vergara declared the mediation was inadmissible and declared; "Chile seeks a stable peace that addresses its current and future interests." Then said there is no reason that could force them to hand over their decisions over their destiny, no matter how honored or steady the next man hands may be". ${ }^{16}$

Before inviting the plenipotentiaries for a next meeting, which would be held on 27 April, Osborn said that both he and his colleagues left record that his Government did not seek the means to become a mediator. "Compliance with such strict duties attached in such charge would cause him much work and hassle and although he had no doubt that his Government would consent to assume the part, in case that was duly offered, however, it should be noted that their representatives are not requesting such deference". ${ }^{33}$ At the last meeting, there was no modification what so ever. The US action aggrieved Chile, who never relied much on them, Osborn was outraged and because he thought he had reached an understanding with Christiancy. Perhaps the greatest Chilean interest was giving an opportunity to Eusebio Lillo so he could have talked with Carrillo and Baptista, a company that also failed.

As noted, the efforts of the US state secretary Evarts were useless. Perhaps they were late and they should have occurred before the start of hostilities. And before Chile's many military triumphs as not to deal with one of the warring stated that had already achieved so much. And would not let them go easily. What will happen the following three years in the Conferences of Arica, regarding these diplomatic peace attempts, which could had probably prevented the atrocities and crimes committed by Chile during the occupation.

\section{Conclusion}

Jesuit Peruvian Historian Rubén Vargas Ugarte, observed a peace chance in Arica, if his Government had accepted the cession of Tarapacá altogether with the protection of regnícolas rights given that the main conditions presented by Chile in these meetings, were allocated a few years later in the Treaty of Ancón with Peru and in the Treaty of peace and friendship on October 20, 1904 with Bolivia, it would have been better for the Allied cause to have accepted them in Arica. This way the conflict would have concluded in eighteen months and not in four years. These conferences meant also a failure for the United States. Evarts decided not to transmit instructions properly to their representatives. These acted motu proprio On January 31, 1881. The New York Herald wrote that the lukewarm diplomatic effort of the United States to achieve peace in 1879 , made them the laughing stock of the South American continent and the recent Arica Conference were predestined to fail from the start. "Any mediation that does not involve an intervention is not worth value of passages of diplomats sent" ${ }^{\prime 34}$ What we want to conclude with this, hoping to enclose these aspects in the historical debate that examines the conflict between these three free and independent Nations, in its darker aspects and in their deeper and more poisonous statements. The main reasons to explain the failure of diplomatic efforts were mainly:

a. The significant achievements and military victories obtained by Chile, during the first years of the conflict.

b. The privileged position of Chile in negotiations, given that the disputed territories were occupied by the latter.

${ }^{16}$ NAUSA vol- 30. Office No. 173, Arica, October 28, 1880, by Thomas Osborn, US Minister in Chile, William M. Evarts, Secretary of State. 
c. The strong international support to the figure of Chile, at the expense of Bolivia and Peru.

d. Poor coordination between the efforts of the Plenipotentiary Ministers accredited in Lima, La Paz and Santiago.

In short, the diplomatic efforts led by the United States to achieve peace in the Pacific, did not come to fruition and however did manage to deflect the European intentions of intervention between the warring South American States.

\section{Acknowledgements}

Part of this study was presented as a paper in the fourth Trinational History encouter carried out at the National University of San Antonio Abad of Cusco, Peru, on 10 and 14 October 2016, under the title: diplomatic relations in the context of the war of Saltpeter 1879-1883.

\section{Conflict of interest}

Author declares there is no conflict of interest in publishing the article.

\section{References}

1. Eyzaguirre J, Echenique GJ. Breve historia de las fronteras de Chile. Editorial Universitaria, Chile. USA; 1967.

2. Maúrtua V. Juicios de límites entre el Perú y Bolivia. Barcelona, Spain; 1906. p. $145-146$.

3. Benadava S. Historia de las fronteras de Chile. Editorial Universitaria, Chile; 1993. p. 17.

4. Jefferson WD. Documentary history of the Tacna-Arica dispute. Kennikat Press, USA; 1927. p. 30.

5. Villalobos S. Chile y Perú. La Historia que nos une y nos separa 1535 1883. Historia, Chile; 2002. p. 86.

6. Cariola C, Sunkel O. Un siglo de historia económica de Chile. 18301930. Editorial Universitaria, Chile; 1990. p. 85.

7. Encina F. Historia de Chile Editorial Nascimiento. Chile: Tomo XVI; 1950. p. 251.

8. Mayo J. La compañía de salitre de Antofagasta y la Guerra del Pacifico. Revista Historia, Instituto de Historia. Chile; 1979. p. 77.

9. Mellington H. American Diplomacy and the war of the Pacific. Columbia University Press, USA; 1948. p. 30.

10. Bello A. Informes inéditos de diplomáticos extranjeros durante la Guerra del Pacifico. Libroselcidcampeador, Chile; 1980.

11. Bulnes G. Guerra del Pacifico. SA Santiago; 1955;2:229-230.

12. Schoultz L. Debajo de los Estados Unidos: una historia de la política estadounidense hacia América Latina. Harvard University Press, USA; 2009. p. 34.

13. Álvarez A. The Monroe Doctrine. Oxford University Press, USA; 1924. p. 6-7.
14. Pascual A. Guerra del Pacifico. Editorial Andrés Bello, Chile: Tomo I; 1982. p. 407.

15. Mellington H. American Diplomacy and the war of the Pacific. Columbia University Press, USA; 1948. p. 55.

16. Mellington H. American Diplomacy and the war of the Pacific. Columbia University Press, USA; 1948. p. 39.

17. Gonzalo Bulnes. Guerra del Pacifico: Editorial del pacific. SA Santiago; $1955 ; 2: 191$.

18. Gonzalo Bulnes. Guerra del Pacifico: Editorial del pacific. SA Santiago; $1955 ; 2: 190$.

19. Krieg WL. Legacy of the War of the Pacific. Department of State Washington DC, Office of External Research, USA; 1974. p. 1-3.

20. Gonzalo Bulnes. Guerra del Pacifico: Editorial del pacific. SA Santiago; 1955;1:249.

21. Candamo JA. Miguel Grau. Instituto de Estudios Históricos, USA; 2003. p. 385 .

22. Basadre J. Historia de la Republica de Perú. Editorial Universitaria, Peru; 1983. p. 77.

23. Mellington H. American Diplomacy and the war of the Pacific. Columbia University Press, USA; 1948. p. 64

24. Mellington H. American Diplomacy and the war of the Pacific. Columbia University Press, USA; 1948. p. 67.

25. Gonzalo Bulnes. Guerra del Pacifico: Editorial del pacific. SA Santiago; $1955 ; 2: 238-239$.

26. Mellington H. American Diplomacy and the war of the Pacific. Columbia University Press, USA; 1948. p. 71.

27. Leonard T. United States Latín American Relation: 1850-1903. University of Alabama Press, USA; 1999. p. 178.

28. Pascual A. Guerra del Pacifico. Editorial Andrés Bello, Chile: Tomo I; 1982. p. 486.

29. Pascual A. Guerra del Pacifico. Editorial Andrés Bello, Chile: Tomo I; 1982. p. 494.

30. Pascual A. Guerra del Pacifico. Editorial Andrés Bello, Chile: Tomo I; 1982. p. 497.

31. Gonzalo Bulnes. Guerra del Pacifico: Editorial del pacific. SA Santiago; 1955;2:249.

32. Pascual A. Guerra del Pacifico. Editorial Andrés Bello, Chile: Tomo III; 1982. p. 499

33. Pascual A. Guerra del Pacifico. Editorial Andrés Bello, Chile: Tomo III; 1982. p. 501

34. Pascual A. Guerra del Pacifico. Editorial Andrés Bello, Chile: Tomo III; 1982. p. 502.

35. Pascual A. Guerra del Pacifico. Editorial Andrés Bello, Chile: Tomo III; 1982. p. 505. 